\title{
Hubungan paparan asap rokok dengan hasil pemeriksaan inspeksi visual asam asetat (IVA) pada wanita usia subur di Puskesmas Tanjung Sekayam
}

\author{
Fikri Yuda Pratama,", Eka Ardiani Putri², Widi Raharjo ${ }^{2}$ \\ ${ }^{I}$ Program Studi Kedokteran, Fakultas Kedokteran, Universitas Tanjungpura, Kalimantan Barat, Indonesia \\ ${ }^{2}$ Departemen Ilmu Kesehatan Masyarakat, Fakultas Kedokteran, Universitas Tanjungpura, Kalimantan Barat, Indonesia \\ *Korespondensi: fikriyudapratama@student.untan.ac.id
}

\begin{abstract}
Abstrak
Latar belakang: Tembakau yang dijadikan rokok selain berdampak pada perokok juga berdampak bagi orang yang tidak merokok. Karsinogen dalam asap rokok dapat menyebabkan kanker salah satunya kanker serviks. Kanker serviks merupakan kanker keempat yang paling sering terjadi pada wanita di dunia. Deteksi dini kanker serviks dapat dilakukan dengan metode inspeksi visual asam asetat (IVA). Tujuan penelitian ini untuk mengetahui hubungan paparan asap rokok dengan hasil IVA pada wanita usia subur. Metode: Penelitian ini merupakan penelitian analitik observasional dengan desain cross-sectional. Subjek penelitian adalah wanita di wilayah kerja Puskesmas Tanjung Sekayam yang melakukan pemeriksaan IVA. Sebanyak 40 wanita usia 30-50 tahun dipilih dengan metode consecutive sampling. Analisis dilakukan dengan uji Fisher. Hasil: Tiga puluh wanita terpapar asap rokok (75\%), 39 wanita memiliki hasil IVA negatif (97,5\%). Analisis bivariat paparan asap rokok dan hasil IVA diperoleh nilai p 1,000, intensitas paparan asap rokok per hari dan hasil IVA wanita terpapar asap rokok diperoleh nilai p 0,433, durasi paparan asap rokok per hari dan hasil IVA wanita terpapar asap rokok diperoleh nilai p 0,367. Kesimpulan: Tidak terdapat hubungan antara paparan asap rokok dengan hasil IVA, serta tidak terdapat hubungan antara intensitas dan durasi paparan asap rokok per hari dengan hasil IVA wanita terpapar asap rokok.
\end{abstract}

Kata kunci: hasil pemeriksaan IVA, kanker serviks, paparan asap rokok

\section{Relationship between secondhand smoke exposure and visual inspection with acetic acid (VIA) results in women of childbearing age at Tanjung Sekayam Public Health Center}

\begin{abstract}
Background: Tobacco smoking does not only affect smokers but also affects people who do not smoke. Carcinogens in cigarette smoke may cause cancer, one of which is cervical cancer. Cervical cancer is the fourth most common cancer in women worldwide. Early detection of cervical cancer can be done with visual inspection with acetic acid (VIA) test. The study aimed to determine the relationship between secondhand smoke exposure to VIA test results in women of childbearing age. Methods: The study was an observational analytic study with a cross-sectional approach. Subjects of this study were women in the working area of the Puskesmas Tanjung Sekayam who underwent VIA examinations. As many as 40 women aged 30-50 years were selected using consecutive sampling. Analysis was performed by Fisher test. Results: Thirty women were exposed to secondhand smoke $(75 \%)$ and 39 women had negative VIA test results $(97.5 \%)$. Bivariate analysis of secondhand smoke exposure and VIA test results obtained a p-value of 1,000, intensity of secondhand smoke exposure per day, and VIA test results obtained p-value of 0.433 , duration of secondhand smoke exposure and VIA test results obtained p-value of 0.367 . Conclusions: There is no relationship between secondhand smoke exposure and VIA results or between the intensity and duration of secondhand smoke exposure with VIA results in women exposed to secondhand smoke.
\end{abstract}

Keywords: cervical cancer, secondhand smoke, VIA results 


\section{Pendahuluan}

World Health Organization (WHO) menyatakan bahwa penggunaan tembakau merupakan salah satu ancaman terbesar bagi kesehatan masyarakat yang pernah dihadapi dunia. Penggunaan tembakau secara langsung telah menewaskan lebih dari 6 juta orang per tahun. Sekitar 890.000 orang tidak merokok mengalami kematian akibat paparan asap rokok orang lain. ${ }^{1,2}$

Paparan asap rokok adalah paparan asap tembakau bekas, baik asap utama yang dihisap oleh perokok aktif dan asap sampingan dari rokok yang dibakar maupun berbagai peralatan merokok lainnya yang telah bercampur dengan udara sekitar yang diterima seseorang yang tidak merokok (perokok pasif). ${ }^{3,4}$ Data Global Adult Tobacco Survey (GATS) menunjukkan bahwa 1,2 miliar orang terpapar asap rokok di tempat umum, 392 juta orang terpapar asap rokok di tempat kerja, dan 1,5 miliar orang terpapar asap rokok di rumah. ${ }^{5}$ Frekuensi orang yang berada di dekat orang yang merokok di dalam ruangan tertutup di Indonesia sebesar 76,5\% dengan persentase laki-laki sebesar 75,9\% dan perempuan 75,3\%. Persentase di Kalimantan barat memiliki angka yang cukup tinggi dengan persentase $79,8 \%{ }^{6}$

Asap dari rokok tembakau mengandung lebih dari 7.000 zat kimia, ratusan diantara zat kimia tersebut bersifat racun dan sekitar 70 bahan kimia yang terkandung dapat menyebabkan kanker. Paparan asap rokok dapat menyebabkan kanker hampir di setiap bagian tubuh seperti hati, payudara, serviks, kandung kemih, darah, serviks, usus besar dan rektum, kerongkongan, ginjal dan ureter, pangkal tenggorokan, hati, orofaring, pankreas, trakea, bronkus, dan paru-paru. $^{7}$

Paparan asap rokok dapat meningkatkan risiko terjadinya kanker serviks. ${ }^{8}$ Perokok pasif di kalangan bukan merokok memiliki risiko yang lebih tinggi mengalami cervical intraepithelial neoplasia (CIN)1. ${ }^{9}$ Wanita bukan perokok yang mendapat paparan asap rokok memiliki risiko $73 \%$ lebih besar terjadinya kanker serviks dibandingkan wanita bukan perokok yang tidak terpapar asap rokok. ${ }^{10}$

Kanker serviks merupakan kanker keempat yang paling sering terjadi pada wanita. Diperkirakan 570.000 kasus baru terjadi mewakili 6,6\% dari seluruh kanker yang dialami perempuan pada tahun 2018. Sekitar $90 \%$ kematian yang disebabkan kanker serviks terjadi di negara berpenghasilan rendah dan menengah. ${ }^{11}$ Data International Agency for Research on Cancer (IARC) menunjukkan kasus baru kanker serviks di Indonesia menempati peringkat kedua dengan persentase sebesar 10,69\% setelah kanker payudara pada tahun 2018. Angka mortalitas yang disebabkan kanker serviks di Indonesia menempati peringkat ketiga dengan persentase sebesar 10,27\% setelah kanker paru dan kanker payudara. ${ }^{12}$

Angka kematian kanker serviks yang tinggi disebabkan kanker lebih sering dideteksi pada stadium lanjut. Salah satu metode yang direkomendasikan yang dapat digunakan untuk deteksi dini kanker serviks sebelum kanker (lesi prakanker) dengan metode inspeksi visual asam asetat (IVA). ${ }^{13}$ Pemeriksaan inspeksi visual asam asetat (IVA) adalah pemeriksaan leher rahim secara visual menggunakan asam asetat dengan mata telanjang untuk mendeteksi abnormalitas setelah pengolesan asam cuka 3-5\%. ${ }^{14}$ Wanita usia 30-50 yang sudah melakukan deteksi dini kanker serviks di Indonesia dengan IVA sebanyak 2.747.662 orang (7,34\%) orang dengan hasil positif 77.969 orang dan di Provinsi Kalimantan Barat sebanyak 40.499 $(6,09 \%)$ dengan hasil positif sebanyak 1.505 orang hingga tahun 2018. ${ }^{15}$ Pemeriksaan IVA yang dilakukan pada wanita usia 30-50 tahun menunjukkan sebanyak 33 orang $(2,09 \%)$ dengan hasil positif dari 1.582 orang $(27,24 \%)$ yang melakukan pemeriksaan IVA di Kabupaten Sanggau hingga tahun $2018 .^{16}$

Tujuan dari penelitian ini untuk mengetahui hubungan paparan asap rokok terhadap hasil pemeriksaan inspeksi visual asam asetat (IVA) pada wanita usia subur di Puskesmas Tanjung Sekayam Kecamatan Kapuas Kabupaten Sanggau yang dilaksanakan pada tahun 2020.

\section{Metode}

Desain penelitian ini adalah analitik observasional dengan menggunakan pendekatan cross-sectional. Subjek penelitian ini diambil dari sejumlah wanita usia subur yang melakukan pemeriksaan IVA di 3 desa berbeda wilayah kerja Puskesmas Tanjung Sekayam. Pengambilan data dilakukan di Poskesdes dari 3 desa berbeda, yaitu Desa Sungai Ranas, Desa Sungai Kosak, dan Desa Penyeladi. Subjek penelitian ini diambil menggunakan non-probability sampling dengan cara consecutive sampling. Sampel diambil sebanyak 40 
wanita usia 30 - 50 tahun yang pernah menikah, belum melakukan pemeriksaan IVA selama 3 tahun terakhir, dan datang melakukan pemeriksaan IVA pada saat penelitian berlangsung. Pengumpulan data dilakukan menggunakan kuesioner dengan metode wawancara terpimpin.

Variabel bebas dalam penelitian ini adalah paparan asap rokok yang dikategorikan menjadi 2 kelompok, yaitu kelompok terpapar asap rokok dan tidak terpapar asap rokok. Identifikasi paparan asap rokok dilakukan dengan menggunakan kuesioner yang terdiri dari 9 pertanyaan yang memuat pertanyaan untuk menggali informasi mengenai sumber paparan asap rokok dari anggota keluarga, intensitas paparan asap rokok yang didapat per hari, dan durasi paparan asap rokok yang didapat per hari. Variabel terikat dalam penelitian ini adalah hasil pemeriksaan IVA yang dikategorikan sebagai IVA positif dan IVA negatif. Pemeriksaan IVA dalam penelitian ini dibantu oleh petugas kesehatan dari Puskesmas Tanjung Sekayam. Pemeriksaan IVA dilakukan untuk melihat adanya lesi prakanker, hasil IVA dinyatakan positif ditandai dengan terbentuknya area acetowhite setelah pengolesan asam cuka 3-5\%.

Wanita yang merokok secara aktif, wanita dengan jumlah pasangan lebih dari 1, dan wanita dengan paritas lebih dari 3 kali dieksklusikan dalam penelitian ini. Analisis data yang digunakan dalam penelitian ini adalah analisis univariat dan bivariat dengan menggunakan aplikasi SPSS 23. Analisis bivariat dilakukan dengan menggunakan uji Fisher.

\section{Hasil}

\section{Karakteristik Responden}

Karakteristik responden dalam penelitian ini meliputi usia, tingkat pendidikan, dan pekerjaan yang disajikan pada Tabel 1. Sebagian besar responden penelitian masuk dalam kategori usia 30-35 tahun (37,5\%), tingkat pendidikan SD $(55,5 \%)$, dan sebagai ibu rumah tangga $(85 \%)$.

\section{Analisis Univariat}

Analisis univariat meliputi paparan asap rokok, intensitas dan durasi paparan asap rokok per hari, serta hasil pemeriksaan IVA yang disajikan pada Tabel 2. Sebagian besar responden penelitian terpapar asap rokok $(75 \%)$, mendapatkan intensitas paparan $\leq 10$ batang per hari $(56,7 \%)$ pada responden terpapar asap rokok, terpapar <2 jam per hari $(63,3 \%)$ pada responden terpapar asap rokok, dan memperoleh hasil IVA negatif $(97,5 \%)$.

Tabel 1. Karakteristik responden

\begin{tabular}{lcc}
\hline Karakteristik Responden & $\mathrm{N}$ & $\%$ \\
\hline Usia (Tahun) & 15 & 37,5 \\
$30-35$ & 12 & 30 \\
$36-40$ & 7 & 17,5 \\
$41-45$ & 6 & 15 \\
$46-50$ & 40 & 100 \\
Total & & \\
Pendidikan & 2 & 5 \\
Tidak sekolah & 22 & 55,5 \\
SD & 9 & 22,5 \\
SMP & 6 & 15 \\
SMA & 1 & 2,5 \\
Perguruan tinggi & 40 & 100 \\
Total & & \\
Pekerjaan & 34 & 85 \\
Ibu rumah tangga & 4 & 10 \\
Nelayan & 2 & 5 \\
Penoreh getah & 40 & 100 \\
Total & & \\
Sumber: Data primer, 2020. & &
\end{tabular}

Tabel 2. Analisis univariat

\begin{tabular}{lcc}
\hline \multicolumn{1}{c}{ Analisis univariat } & $\mathrm{N}$ & $\%$ \\
\hline Paparan asap rokok & & \\
$\quad$ Tidak terpapar & 10 & 25 \\
$\quad$ Terpapar & 30 & 75 \\
$\quad$ Total & 40 & 100 \\
Intensitas paparan asap rokok per hari & & \\
$\quad \leq 10$ batang & 17 & 56,7 \\
$\quad>10$ batang & 13 & 43,3 \\
$\quad$ Total & 30 & 100 \\
Durasi paparan asap rokok per hari & & \\
$\quad<2$ jam & 19 & 63,3 \\
$\quad$ 22 jam & 11 & 36,7 \\
$\quad$ Total & 30 & 100 \\
Hasil pemeriksaan IVA & & \\
$\quad$ IVA positif & 1 & 2,5 \\
$\quad$ IVA negatif & 39 & 97,5 \\
$\quad$ Total & 40 & 100 \\
\hline Sumber: Data primer, 2020. & &
\end{tabular}

\section{Analisis Bivariat}

Hubungan antara intensitas paparan asap rokok per hari terhadap hasil pemeriksaan IVA wanita terpapar asap rokok, dan hubungan durasi paparan asap rokok per hari terhadap hasil pemeriksaan IVA wanita terpapar asap rokok ditunjukkan pada Tabel 3.

Hasil uji Fisher untuk menilai hubungan paparan asap rokok terhadap hasil pemeriksaan IVA menunjukkan nilai $p=1,000$. Hal ini menunjukkan bahwa tidak terdapat hubungan antara paparan asap rokok terhadap hasil pemeriksaan IVA dalam penelitian ini. 
Tabel 3. Hubungan paparan asap rokok terhadap hasil pemeriksaan IVA

\begin{tabular}{|c|c|c|c|c|c|c|c|c|}
\hline & & \multicolumn{4}{|c|}{ Hasil Pemeriksaan IVA } & \multirow{2}{*}{\multicolumn{2}{|c|}{ Total }} & \multirow{3}{*}{ Nilai p } \\
\hline & & \multicolumn{2}{|c|}{ Positif } & \multicolumn{2}{|c|}{ Negatif } & & & \\
\hline & & $\mathrm{N}$ & $\%$ & $\mathrm{~N}$ & $\%$ & $\mathrm{~N}$ & $\%$ & \\
\hline \multirow[t]{3}{*}{ Paparan asap rokok } & Tidak terpapar & 0 & 0 & 10 & 25 & 10 & 25 & \multirow{3}{*}{1,000} \\
\hline & Terpapar & 1 & 2,5 & 29 & 72,5 & 30 & 75 & \\
\hline & Total & 1 & 2,5 & 39 & 97,5 & 40 & 100 & \\
\hline
\end{tabular}

Sumber: Data primer, 2020

Tabel 4. Hubungan intensitas dan durasi paparan asap rokok terhadap hasil pemeriksaan IVA

\begin{tabular}{|c|c|c|c|c|c|c|c|c|}
\hline \multirow{3}{*}{ Paparan asap rokok } & & \multicolumn{4}{|c|}{ Hasil Pemeriksaan IVA } & \multirow{2}{*}{\multicolumn{2}{|c|}{ Total }} & \multirow{3}{*}{ Nilai $\mathrm{p}$} \\
\hline & & \multicolumn{2}{|c|}{ Positif } & \multicolumn{2}{|c|}{ Negatif } & & & \\
\hline & & $\mathrm{N}$ & $\%$ & $\mathrm{~N}$ & $\%$ & $\mathrm{~N}$ & $\%$ & \\
\hline \multirow[t]{3}{*}{ Intensitas paparan per hari } & $\leq 10$ batang & 0 & 0 & 17 & 56,7 & 17 & 56,7 & 0,433 \\
\hline & $>10$ batang & 1 & 3,3 & 12 & 40 & 13 & 43,3 & \\
\hline & Total & 1 & 3,3 & 29 & 96,7 & 30 & 100 & \\
\hline \multirow[t]{3}{*}{ Durasi paparan per hari } & $<2$ jam & 0 & 0 & 19 & 63,3 & 19 & 63,3 & 0,367 \\
\hline & $\geq 2$ jam & 1 & 3,3 & 10 & 33,4 & 11 & 36,7 & \\
\hline & Total & 1 & 3,3 & 29 & 96,7 & 30 & 100 & \\
\hline
\end{tabular}

Sumber: Data primer, 2020

Hasil analisis bivariat dengan menggunakan uji Fisher untuk menguji hubungan intensitas paparan asap rokok per hari terhadap hasil pemeriksaan IVA wanita terpapar asap rokok menunjukkan nilai $\mathrm{p}=0,433$. Hasil analisis bivariat dengan menggunakan uji Fisher untuk menguji hubungan durasi paparan asap rokok per hari terhadap hasil pemeriksaan IVA wanita terpapar asap rokok didapatkan $\mathrm{p}=0,367$. Hal ini diartikan bahwa tidak terdapat hubungan antara intensitas paparan asap rokok per hari terhadap hasil pemeriksaan IVA wanita terpapar asap rokok dan tidak terdapat hubungan antara durasi paparan asap rokok per hari terhadap hasil pemeriksaan IVA wanita terpapar asap rokok dalam penelitian ini.

\section{Pembahasan}

\section{Karakteristik responden}

Hasil penelitian yang dilakukan pada wanita usia 30-50 tahun menunjukkan bahwa sebagian besar responden berusia 30-35 tahun (37,5\%). Berdasarkan tingkat pendidikan sebagian besar responden memiliki tingkat pendidikan SD dengan jumlah responden 22 orang $(55 \%)$. Sebagian besar responden adalah ibu rumah tangga dengan jumlah responden 34 orang (85\%).

Kelompok usia 31-45 tahun merupakan kelompok usia yang berisiko mengalami lesi prakanker. Lesi prakanker yang tidak ditangani akan berkembang menjadi kanker dalam waktu 10-20 tahun. ${ }^{17,18}$ Perempuan yang memiliki tingkat pendidikan lebih tinggi memiliki tingkat kepatuhan yang lebih tinggi dibandingkan perempuan dengan tingkat pendidikan yang lebih rendah untuk melakukan skrining kanker serviks. ${ }^{19}$ Perempuan yang bekerja memiliki kemungkinan yang lebih sering beraktivitas di luar rumah dan berinteraksi dengan orang lain sehingga lebih banyak mendapatkan informasi seperti informasi mengenai kanker serviks. $^{20}$

\section{Analisis univariat}

Penelitian ini menunjukkan sebagian besar responden terpapar asap rokok dengan jumlah responden sebanyak 30 orang (75\%). Hasil penelitian ini berbeda dengan penelitian yang dilakukan oleh Ursia dkk yang menunjukkan sebagian besar responden tidak terpapar asap rokok dengan persentase 74,3\%. ${ }^{21}$ Data Riset Kesehatan Dasar (Riskesdas) tahun 2018 menunjukkan sebagian besar perempuan mendapat paparan asap rokok dengan persentase sebesar $75,3 \%$, sebesar $34,8 \%$ diantaranya mendapatkan paparan asap rokok setiap hari. Persentase paparan asap rokok lebih tinggi terjadi di pedesaan dengan persentase sebesar $79,3 \%$ dibandingkan perkotaan dengan persentase sebesar $72,5 \%{ }^{6}$ 
Hasil pemeriksaan inspeksi visual asam asetat (IVA) responden penelitian menunjukkan sebagian besar responden mendapatkan hasil negatif dengan jumlah responden sebanyak 39 orang $(97,5 \%)$ dan jumlah responden dengan hasil positif sebanyak 1 orang $(2,5 \%)$. Berdasarkan intensitas paparan asap rokok per hari dan durasi paparan asap rokok per hari, responden dengan hasil IVA positif mendapatkan intensitas paparan sebesar $>10$ batang per hari dengan durasi paparan $\geq 2$ jam dalam satu hari. Pada kelompok dengan hasil IVA negatif sebagian besar responden mendapatkan intensitas paparan asap rokok $\leq 10$ batang per hari dengan durasi paparan sebagian besar $<2$ jam dalam satu hari.

Penelitian yang dilakukan oleh An dkk menunjukkan sebagian besar responden dengan gambaran sitologi serviks abnormal mendapatkan intensitas paparan asap rokok per hari $>10$ batang dengan persentase sebesar $61 \% .^{22}$ Penelitian yang dilakukan Min dkk menunjukkan sebagian besar responden yang terpapar asap rokok yang mengalami cervical intraepithelial neoplasia (CIN) 1 mendapatkan paparan asap rokok $<2$ jam dalam satu hari, sebagian besar responden yang terpapar asap rokok yang mengalami cervical intraepithelial neoplasia (CIN) 2/3 mendapatkan paparan asap rokok $\geq 2$ jam dalam satu hari, dan sebagian besar responden yang terpapar asap rokok yang mengalami kanker serviks mendapatkan paparan asap rokok $<2$ jam dalam satu hari. ${ }^{9}$

Rendahnya hasil positif IVA dapat dipengaruhi oleh penurunan signifikan sensitivitas deteksi dini lesi prakanker dengan metode IVA yang terjadi pada wanita setelah berusia lebih dari 40 tahun. Penurunan sensitivitas IVA terjadi dikarenakan berkurangnya kemampuan inspeksi visual untuk mendeteksi perubahan yang terjadi di zona transformasi. Hal ini terjadi akibat penyusutan zona transformasi yang bergeser ke kanalis endoservikalis pada wanita pascamenopause. ${ }^{23}$

\section{Hubungan paparan asap rokok terhadap hasil pemeriksaan IVA}

Hasil analisis yang didapatkan menunjukkan tidak terdapat hubungan antara paparan asap rokok terhadap hasil pemeriksaan IVA $(p=1,000)$. Hasil penelitian ini berbeda dengan hasil penelitian yang dilakukan oleh Ursia dkk yang menunjukkan terdapat hubungan antara perempuan yang mendapatkan paparan asap rokok terhadap hasil positif IVA (OR 2,29; CI 95\%). ${ }^{21}$ Penelitian ini sejalan dengan penelitian An dkk yang menunjukkan tidak terdapat hubungan antara paparan asap rokok yang didapat di rumah terhadap terjadinya lesi pada serviks. $^{22}$ Penelitian Feng dkk menunjukkan pada wanita yang mendapatkan paparan asap rokok berhubungan secara signifikan terhadap terjadinya infeksi HPV (OR 1,12; CI 95\%), namun tidak berhubungan secara signifikan terhadap terjadinya CIN2+ (OR 0,80; CI 95\%). ${ }^{24}$

Berdasarkan intensitas paparan asap rokok per hari, hasil analisis yang didapatkan menunjukkan tidak terdapat hubungan antara intensitas paparan asap rokok per hari terhadap hasil pemeriksaan IVA wanita terpapar asap rokok $(p=0,433)$. Penelitian ini sejalan dengan penelitian An dkk yang menunjukkan bahwa tidak terdapat hubungan antara intensitas paparan asap rokok yang didapat di rumah terhadap lesi serviks. ${ }^{22}$ Wanita yang terpapar asap rokok 1,57 kali lebih berisiko mengalami high-grade squamous intraepithelial lesion (HSIL) dibandingkan dengan responden yang tidak terpapar. Peningkatan risiko ini terjadi dari 1,64 kali pada kelompok dengan tingkat paparan rendah menjadi 1,71 kali pada kelompok dengan tingkat paparan tinggi. ${ }^{25}$

Berdasarkan durasi paparan asap rokok per hari, hasil analisis yang didapatkan menunjukkan tidak terdapat hubungan antara durasi paparan asap rokok per hari terhadap hasil pemeriksaan IVA wanita terpapar asap rokok $(p=0,367)$. Penelitian ini berbeda dengan penelitian Min dkk yang menunjukkan terdapat hubungan antara paparan asap rokok dengan terjadinya cervical intraepithelial neoplasia 1 (CIN 1). Risiko ini semakin meningkat pada perempuan yang tidak merokok yang mendapat paparan asap rokok dari orang lain lebih dari 2 jam dalam satu hari. ${ }^{9}$ Paparan asap rokok pada wanita dibandingkan dengan wanita yang tidak mendapat paparan asap rokok menjadi faktor independen terjadinya abnormalitas pada gambaran sitologi serviks. Semakin meningkat jumlah jam terpapar asap rokok semakin tinggi insidensi terjadinya low-grade squamous intraepithelial lesion (LSIL). ${ }^{26}$

Paparan asap rokok yang terjadi secara terus-menerus selama masa kehidupan dapat meningkatkan risiko terjadinya kanker. Perempuan yang tidak merokok memiliki risiko 4,8 kali lebih besar terjadinya lesi prakanker leher rahim dibandingkan perempuan yang tidak mendapat paparan asap rokok dari orang lain. ${ }^{27}$ Mekanisme ini 
dikaitkan dengan zat berbahaya dan karsinogen yang terdapat di dalam asap rokok seperti nikotin, cotinine, benzo[a]pyrene, dan 4-(methylnitrosamino) -1-(3-pyridyl)-1-butanone. ${ }^{27}$ Berbagai zat berbahaya yang terdapat dalam asap rokok dapat menyebabkan infeksi melalui mekanisme bawaan dan humoral. Zat berbahaya tersebut selain menyebabkan cedera akibat efek toksik pada sel epitel juga dapat meningkatkan produksi molekul-molekul adhesif yang dapat menyebabkan penetrasi virus lebih mudah ke dalam sel epitel sehingga mengakibatkan timbulnya penyakit. Respon humoral sistem imun juga mengalami gangguan signifikan akibat paparan asap rokok. Asap rokok menghambat aktivitas sel $\mathrm{T}$ dan natural killer cell (NK) serta dapat menekan produksi antibodi spesifik HPV. Sel T helper 1 berfungsi menstimulasi sel $\mathrm{B}$ untuk menghasilkan jenis antibodi spesifik dan sel NK dapat menghasilkan respon sitotoksik pada sel tertentu. ${ }^{28,29}$

Wanita yang mendapatkan paparan asap rokok dari suami yang merokok memiliki risiko yang lebih tinggi mengalami lesi prakanker. Risiko ini semakin meningkat pada wanita dengan suami yang memiliki intensitas merokok yang lebih tinggi. ${ }^{30}$ Paparan asap tembakau menyebabkan penurunan respon imun lokal terhadap infeksi HPV. Sel yang terinfeksi HPV dan mendapat paparan karsinogen dari asap rokok seperti benzo(a)pyrene (BaP), dapat menyebabkan kerusakan DNA yang dapat mengakibatkan proses terjadinya pencegahan apoptosis dan penghentian siklus sel. $^{31}$

Nikotin yang terdapat dalam asap rokok dapat menjadi prediktor terjadinya infeksi high-risk HPV (HR-HPV). Perempuan yang mendapatkan nikotin dari paparan asap rokok memiliki risiko yang lebih tinggi terinfeksi HR-HPV. Nikotin dapat mendorong proliferasi pada sel yang diinduksi HPV melalui jalur persinyalan RPS27a-Mdm2-P53. Nikotin menyebabkan penurunan ekspresi ribosomal protein S27a (RPS27a) yang berikatan dengan murine double minute 2 ( $\mathrm{Mdm} 2)$, sehingga tidak dihambatnya ubiquitinasi dan degradasi p53 yang dimediasi Mdm2. Nikotin juga mendorong terjadinya fosforilasi Mdm2 mengakibatkan ubiquitinasi p53 sehingga terjadi penurunan stabilisasi p53. Akibatnya terjadi penurunan jumlah p53 serta ekspresi p53/p21 yang berperan mencegah pertumbuhan sel sehingga terjadi proliferasi sel. ${ }^{31,32}$

Mekanisme lain yang dapat mungkin terjadi yaitu pada laki-laki yang memiliki kebiasaan merokok memiliki risiko yang lebih tinggi untuk terinfeksi HPV onkogenik. Risiko infeksi HPV semakin meningkat pada laki-laki yang merokok $\geq 10$ batang/hari. ${ }^{33,34}$ Penile HPV ditemukan lebih tinggi pada suami yang memiliki kebiasaan merokok. Hal ini menunjukkan bahwa suami yang merokok aktif lebih cenderung mengalami infeksi persisten HPV dibandingkan dengan suami yang tidak merokok, sehingga memiliki kemungkinan lebih tinggi untuk menularkan virus HPV pada pasangannya. Penularan high-risk HPV dari suami meningkatkan risiko terjadinya lesi prakanker dan kejadian kanker pada pasangannya. ${ }^{30,35}$

Hubungan antara durasi terpapar asap rokok dan terinfeksi virus HPV memegang peranan penting dalam perjalanan terjadinya proses karsinogenesis pada serviks. Durasi paparan asap rokok yang lebih lama dan periode singkat infeksi HPV memiliki kemungkinan tidak terjadinya CIN. ${ }^{9}$ Nikotin dan berbagai substansi berbahaya dari asap rokok dapat ditemukan pada mukus yang dihasilkan jaringan epitel serviks dari wanita yang tidak merokok. ${ }^{30,36,37}$ Substansi berbahaya seperti nikotin dalam asap rokok dapat diserap oleh tubuh dan didistribusikan ke seluruh tubuh melalui sirkulasi darah yang kemudian akan dikeluarkan secara bertahap. Hal ini menyebabkan durasi terpapar nikotin dan zat berbahaya lainnya harus bertahan cukup lama untuk dapat menyebabkan lesi pada serviks. ${ }^{22,38}$

Infeksi HR-HPV persisten memegang peranan penting untuk terbentuknya lesi prakanker pada serviks. Mekanisme clearance dari virus HPV pada umumnya terjadi dalam jangka waktu 6-12 bulan. Clearance virus HPV terjadi pada 40,4\% dari total keseluruhan wanita yang mengalami infeksi virus HPV. Akibat dari mekanisme tersebut infeksi virus HPV persisten dapat dicegah sehingga tidak berkembang membentuk lesi prakanker pada serviks. $^{35,39}$

Keterbatasan dalam penelitian ini diantaranya adalah identifikasi paparan asap rokok hanya menggunakan pertanyaan yang dijawab dari ingatan responden dan tidak diukur menggunakan pemeriksaan biokimia sehingga dapat menimbulkan bias, tidak adanya data mengenai infeksi HPV sebagai faktor utama munculnya lesi pada serviks, dan tidak semua faktor risiko yang dapat menjadi variabel perancu dapat dikendalikan. 


\section{Kesimpulan}

Berdasarkan penelitian ini dapat disimpulkan tidak terdapat hubungan yang bermakna secara statistik antara paparan asap rokok terhadap hasil pemeriksaan IVA, tidak terdapat hubungan bermakna secara statistik antara intensitas paparan asap rokok per hari terhadap hasil pemeriksaan IVA wanita usia subur yang terpapar asap rokok, dan tidak terdapat hubungan bermakna secara statistik antara durasi paparan asap rokok per hari terhadap hasil pemeriksaan IVA wanita usia subur yang terpapar asap rokok di wilayah kerja Puskesmas Tanjung Sekayam Kecamatan Kapuas Kabupaten Sanggau.

\section{Daftar Pustaka}

1. World Health Organization. Tobacco [Internet] Who.int. 2018 [cited 2019 Feb 9]. Available from: https://www.who.int/news-room/fact-sheets/detail/tob acco

2. World Health Organization. Prevalence of tobacco smoking [Internet]. Who.int. 2016 [cited 2019 Feb 9]. Available from: http://www.who.int/gho/tobacco/ use/en/

3. World Health Organization. Second-hand tobacco smoke [Internet]. Who.int. 2015 [cited 2019 May 8]. Available from: https://www.who.int/tobacco/ research/secondhand_smoke/en/

4. American Cancer Society. Health risks of secondhand smoke [Internet]. Cancer.org. 2015 [cited 2019 May 8]. Available from: https://www.cancer.org/cancer/ cancer-causes/tobacco- and -cancer/ secondhandsmoke.html

5. Asma S, Mackay J, Song SY, Zhao L, Morton J, Bettcher KMPD, et al. The GATS atlas: global adult tobacco survey. Atlanta: CDC Foundation; 2015.

6. Badan Penelitian dan Pengembangan Kesehatan. Riset Kesehatan Dasar 2018. Kementerian Kesehatan RI; 2018.

7. U.S. Department of Health and Human Services. The health consequences of smoking - 50 years of progress: a report of the surgeon general [Internet]. Rockville: American Psychological Association; 2014 [cited 2019 Feb 10]. Available from: http://doi.apa.org/get-pe-doi.cfm?doi=10.1037/e51007 2014-001

8. Su B, Qin W, Xue F, Wei X, Guan Q, Jiang W, et al. The relation of passive smoking with cervical cancer: A systematic review and meta-analysis. Medicine (Baltimore). 2018;97(46):e13061.

9. Min K-J, Lee J-K, So KA, Kim MK. Association between passive smoking and the risk of cervical intraepithelial neoplasia 1 in Korean women. J Epidemiol. 2018;28(1):48-53.

10. Zeng X-T, Xiong P-A, Wang F, Li C-Y, Yao J, Guo Y. Passive smoking and cervical cancer risk: a meta-analysis based on 3,230 cases and 2,982 controls. Asian Pac J Cancer Prev. 2012;13:2688-91.
11. World Health Organization. Cervical cancer [Internet]. Who.int. 2019 [cited 2019 Feb 10]. Available from: http://www.who.int/cancer/prevention/diagnosis-scree ning/cervical-cancer/en/

12. International Agency for Research on Cancer. Indonesia - global cancer observatory [Internet]. World Health Organization; 2019. Available from: http://gco.iarc.fr/today/data/factsheets/populations/360 -indonesia-fact-sheets.pdf

13. Kementerian Kesehatan RI. Profil kesehatan Indonesia tahun 2017. Jakarta: Kementerian Kesehatan RI; 2018.

14. Kementerian Kesehatan RI. Penanggulangan kanker payudara dan kanker leher rahim. Jakarta: Kementerian Kesehatan RI; 2015.

15. Kementerian Kesehatan RI. Data dan informasi profil kesehatan Indonesia 2018. Jakarta: Kementerian Kesehatan RI; 2019.

16. Dinas Kesehatan Kabupaten Sanggau. Profil kesehatan Kabupaten Sanggau 2018. Sanggau: Dinas Kesehatan Kabupaten Sanggau; 2019.

17. Nkfusai NC, Mubah TM, Yankam BM, Tambe TA, Cumber SN. Prevalence of precancerous cervical lesions in women attending Mezam Polyclinic Bamenda, Cameroon. Pan Afr Med J. 2019;32:174.

18. World Health Organization. Comprehensive cervical cancer control: a guide to essential practice. 2 nd ed. Geneva: World Health Organization; 2014.

19. Damiani G, Basso D, Acampora A, Bianchi CBNA, Silvestrini G, Frisicale EM, et al. The impact of level of education on adherence to breast and cervical cancer screening: Evidence from a systematic review and meta-analysis. Prev Med. 2015;81:281-9.

20. Mesalina R, Sulung N, Nurhayati. Sosio demografi perempuan pemanfaatan deteksi dini kanker serviks metode IVA di Bukittinggi. J Hum Care. 2019;4(2):64-75.

21. Ursia CC, Warsanto J, Isbadianti E. Visual inspection with acetic acid (VIA) positive result and passive smoker in Puskesmas Wonoayu Sidoarjo. Journal of Widya Medika Junior. 2020;2(2):86-94.

22. An L, Zhou X, Li W, Wang Y, Shi H, Xie T. Association between secondhand smoke exposure and abnormal cervical cytology: A one-to-one matched case-control study. Tob Induc Dis. 2018;16:56.

23. Chung MH, McKenzie KP, De Vuyst H, Richardson BA, Rana F, Pamnani R, et al. Comparing Papanicolau smear, visual inspection with acetic acid and human papillomavirus cervical cancer screening methods among HIV-positive women by immune status and antiretroviral therapy. AIDS Lond Engl. 2013;27(18):2909-19.

24. Feng R-M, Hu S-Y, Zhao F-H, Zhang R, Zhang X, Wallach AI, et al. Role of active and passive smoking in high-risk human papillomavirus infection and cervical intraepithelial neoplasia grade 2 or worse. $\mathbf{J}$ Gynecol Oncol. 2017;28(5):e47.

25. Du X, Li M, Zhou Y, Yang H, Isachenko V, Takagi T, et al. Evidence of passive smoking as a risk factor of high-grade squamous intraepithelial lesion: a case-control study. Biol Pharm Bull. 2020;43(7):1061-6.

26. Ward KK, Berenson AB, Breitkopf CR. Passive smoke exposure and abnormal cervical cytology in a predominantly Hispanic population. Am J Obstet Gynecol. 2011;204(3):213.e1-6.

27. Dewi IGAAN, Sawitri AAS, Adiputra N. Paparan asap rokok dan higiene diri merupakan faktor risiko 
lesi prakanker leher rahim di Kota Denpasar tahun 2012. Public Health Prev Med Arch. 2013;1(1):84-91.

28. Simen-Kapeu A, Kataja V, Yliskoski M, Syrjänen K, Dillner J, Koskela P, et al. Smoking impairs human papillomavirus (HPV) type 16 and 18 capsids antibody response following natural HPV infection. Scand J Infect Dis. 2008;40(9):745-51.

29. Kum-Nji P, Meloy L, Keyser-Marcus L. Tobacco smoke exposure as a risk factor for human papillomavirus infections in women 18-26 years old in the United States. PLOS ONE. 2019;14(10):e0223532.

30. Louie KS, Castellsague X, de Sanjose S, Herrero R, Meijer CJ, Shah K, et al. Smoking and passive smoking in cervical cancer risk: pooled analysis of couples from the IARC multicentric case-control studies. Cancer Epidemiol Biomark Prev. 2011;20(7):1379-90.

31. Ono A, Nakagawa M, Ikuta E, Watanabe Y, Koshiyama M. Relationship between Tobacco Smoking and Cervical Cancer. Women Health Open J. 2019;5(1):19-21.

32. Chen L, Wang H. Nicotine Promotes Human Papillomavirus (HPV)-Immortalized Cervical Epithelial Cells (H8) Proliferation by Activating RPS27a-Mdm2-P53 Pathway In Vitro. Toxicol Sci Off J Soc Toxicol. 2019;167(2):408-18.

33. Schabath MB, Villa LL, Lazcano-Ponce E, Salmerón J, Quiterio M, Giuliano AR. Smoking and Human Papillomavirus (HPV) Infection in the HPV in Men
(HIM) Study. Cancer Epidemiol Biomark Prev. 2012;21(1):102-10.

34. Nielson CM, Harris RB, Dunne EF, Abrahamsen M, Papenfuss MR, Flores R, et al. Risk Factors for Anogenital Human Papillomavirus Infection in Men. J Infect Dis. 2007;196(8):1137-45.

35. Ingles DJ, Lin H-Y, Fulp WJ, Sudenga SL, Lu B, Schabath MB, et al. An analysis of HPV infection incidence and clearance by genotype and age in men: The HPV Infection in Men (HIM) Study. Papillomavirus Res. 2015;1:126-35.

36. Coker AL, Bond SM, Williams A, Gerasimova T, Pirisi L. Active and passive smoking, high-risk human papillomaviruses and cervical neoplasia. Cancer Detect Prev. 2002;26(2):121-8.

37. Seo S-S, Oh HY, Kim MK, Lee DO, Chung YK, Kim $\mathrm{J}-\mathrm{Y}$, et al. Combined effect of secondhand smoking and alcohol drinking on risk of persistent human papillomavirus infection. BioMed Res Int. 2019;2019:1-9.

38. Hwang LY, Ma Y, Benningfield SM, Clayton L, Hanson EN, Jay J, et al. Factors that influence the rate of epithelial maturation in the cervix of healthy young women. J Adolesc Health. 2009;44(2):103-10.

39. Miranda PM, Silva NNT, Pitol BCV, Silva IDCG, Lima-Filho JL, Carvalho RF, et al. Persistence or clearance of human papillomavirus infections in women in Ouro Preto, Brazil. BioMed Res Int. 2013;2013:578276. 